\title{
Saliva secretion and its relation to feeding in cattle
}

\author{
2.* The composition and rate of secretion of mixed \\ saliva in the cow during rest
}

\author{
By C. B. BAILEY† AND C. C. BALCH \\ National Institute for Research in Dairying, Shinfield, Reading \\ (Received 2 December 1960-Revised 21 April г961)
}

Bailey \& Balch (1961 $b$ ) described the secretory characteristics of the right parotid gland of a small steer. Parotid saliva is one of several salivary secretions produced by ruminants (Dukes, I955) and the saliva entering the rumen at any given time is a mixture of the individual fluids. Although little is known of the relative amounts of the different fluids secreted under different conditions, information on the activities of some of the glands is available. Both the parotid and the sublingual glands secrete continuously but, whereas parotid saliva predominates in the mixed fluid (McDougall, I948; Hydén, I958), the amounts of sublingual saliva are relatively very small (Colin, I886). The submaxillary glands are quiescent except during eating, when they may secrete almost as much fluid as the parotid glands (Ellenberger \& Hofmeister, I887). In the opinion of Scheunert, Krzywanek \& Zimmermann (1929-30), mixed saliva may also contain considerable quantities of the secretions of the ventral buccal glands.

Alterations of the rate of secretion of mixed saliva and of the chemical properties of the secretions can occur as a result of changes in the relative amounts of the component fluids. Such alterations could have an important bearing on the control which mixed saliva exercises on the environment within the reticulo-ruminal sac and indirectly on the activities of the micro-organisms responsible for the digestion of food in the reticulo-rumen. Different diets will tend to vary the environment in the reticulorumen, and it is a matter of considerable interest to know what effect the changes might have on the rate of secretion and composition of mixed saliva.

The present communication describes several experiments with cows in which the rate of secretion and chemical properties of mixed saliva were measured at various times relative to the ingestion of different diets. All measurements were made during periods of rest, when the animals were standing but neither eating nor ruminating. A preliminary report of some of this work has been given (Bailey, 1959).

\section{EX P E R I M EN T A L}

Measurement of the rate of secretion of mixed saliva. Mixed saliva was collected quantitatively as it descended into the rumen through the cardia from five dry, Shorthorn cows with long-established rumen fistulas. When saliva secretion was to be

* Paper no. I : Brit. F. Nutr. (196r), I5, 37 I.

$\uparrow$ Present address: Canada Department of Agriculture, Research Station, Lethbridge, Alberta, Canada. 
measured, the bung closing the rumen fistula (Balch \& Johnson, 1948) was removed and the rumen was emptied by hand to the point where free access of the hand to the cardia was possible. The level of the contents in the anterior sac of the rumen was lowered to approximately the level of the relaxed anterior pillar. It was necessary to remove $40-70 \mathrm{lb}$ digesta, depending on the diet and the time of day. The reticulum and the ventral sac of the rumen remained full at all times. The animals generally showed little interest in the emptying procedure and rarely interrupted their activities (e.g. drinking, licking, ruminating) while it took place.

Tactile stimulation of certain areas of the reticulum has been shown to augment the secretion of parotid saliva in sheep (Coats, Denton, Goding \& Wright, I956; Comline \& Titchen, I957; Ash \& Kay, I959). Particular care was exercised, accordingly, to prevent stimulation of the sensitive areas during the emptying procedure and, as an added precaution, about $5 \mathrm{~min}$ were allowed after emptying before saliva collection began.

For the collection of saliva, a small rubber bag (P1. I) was held in the hand and poised near the cardia. When the animal was seen to swallow, the collecting bag was quickly but lightly placed over the cardia, whence the saliva descended into the bag. The bag was then rapidly withdrawn, the volume of saliva was measured and the bag again held in readiness for the next swallow. The 20-40 sec which elapsed between each swallow was a sufficient time for the removal and measurement of the saliva before the next swallow. The bag was held against the cardia for about $3 \mathrm{sec}$ at each swallow and it was assumed that it stimulated no excess flow of saliva. During each of the regular reticulum contractions the level of the fluid in the reticulum rose high enough to submerge the cardia, which did not upset the collecting routine since of about 8000 swallows collected only five or six were during a reticulum contraction. The swallowing of the saliva was not especially related to any other phase of the contraction cycle in the reticulo-rumen.

Two groups of ten swallows each were collected for each estimation. Although large differences were frequently encountered between the secretion rates measured during the first and the second group of ten swallows, the overall mean values calculated from the values for all the cows were very similar: $5^{8 \mathrm{ml}} / \mathrm{min}$ for the first and $59 \mathrm{ml} / \mathrm{min}$ for the second collection. In all instances where individual secretion rates are recorded in this paper they are the means of the first and second collections.

It was frequently observed that during several minutes before rumination began an increase in the rate of secretion of saliva occurred, and, further, that a period of decreased rate occurred immediately after rumination. All saliva collections were made at least $5 \mathrm{~min}$ after a period of rumination, and if rumination occurred within $5 \mathrm{~min}$ of the completion of a period of saliva collection the results were discarded and the collection was repeated. The collection of saliva was frequently interrupted by a period of attempted rumination, especially when the animals consumed diets high in fibre. The rumens were emptied to a level that tended to prevent the regurgitation of digesta. In some animals, however, the attempts were exceedingly persistent and the collection of saliva was then terminated and resumed at least 5 min after the cessation of the attempted rumination. 
Collection of samples for chemical analysis. A representative number, usually ten, of the twenty saliva swallows collected at each measurement of the rate of secretion were mixed and retained for chemical analysis, the remainder being returned to the rumen. Two small subsamples were separated from the main sample and placed one in each of two test-tubes immediately after the main sample was obtained. The tubes were closed with rubber stoppers in such a way that no air spaces appeared between the menisci and the bottoms of the stoppers, which prevented the further loss of $\mathrm{CO}_{2}$. One of the subsamples was used for the measurement of $\mathrm{pH}$ and the other for the determination of $\mathrm{CO}_{2}$ and urea. When the analyses were delayed longer than about $30 \mathrm{~min}$, the rubber bung was removed and a thin layer of liquid paraffin was poured on to the surface of the saliva.

The main saliva sample was centrifuged at $2900 \mathrm{~g}$ in an angle-head for $30 \mathrm{~min}$ to remove fine particles of debris. The centrifuged samples were clear and occasionally faintly coloured. This colour was due to very slight contamination with rumen fluid, and its possible effect on the composition of the sample has been ignored. The samples were kept frozen until ready for analysis. They were analysed for sodium, potassium, chloride, phosphorus (expressed as $\mathrm{HPO}_{4}{ }^{2-}$ ), carbon dioxide (expressed as $\mathrm{HCO}_{3}^{-}$), total nitrogen, urea nitrogen, dry matter and ash. The $\mathrm{pH}$ of saliva and rumen fluid was also determined each time the secretion of saliva was measured. The $\mathrm{pH}$ of the rumen fluid was obtained to give a rough indication of the level of the fermentative reactions occurring in the rumen at any given time. The concentrations of total volatile fatty acids (TVFA) were determined in some of the samples of rumen fluid. The sampling procedure for the rumen fluid has already been described (Bailey \& Balch, I961 $a$ ). The chemical methods were the same as those previously described (Bailey \& Balch, r96r $b$ ).

Table I. Expt I. Mean daily intake of sodium, potassium, chloride and phosphorus by cows receiving the five diets

\begin{tabular}{lrrrr}
\multicolumn{1}{c}{ Diet } & \multicolumn{4}{c}{ Daily intake (g) } \\
\cline { 2 - 5 } & Sodium & Potassium & Chloride & Phosphorus \\
Silage & $14 \cdot 2$ & 177 & 74 & $24 \cdot 6$ \\
Hay & $4 \cdot 7$ & 92 & 33 & $7 \cdot 5$ \\
Hay and dairy cubes & $16 \cdot 0$ & 105 & 44 & $40 \cdot 1$ \\
Hay, flaked maize and groundnut cake & $6 \cdot 6$ & 38 & 7 & $12 \cdot 4$ \\
Grass & 4.7 & 244 & 124 & 24.8
\end{tabular}

About sixty samples of jugular venous blood were withdrawn from four cows in Expts $I$ and 5 within $I_{5}$ min of the collection of the saliva samples. The urea content of plasma from these samples was determined by the technique of Conway (I957).

Feeding procedure. In all experiments the cows were given food twice daily, at $07.30 \mathrm{~h}$ and $17.00 \mathrm{~h}$, and received half their daily quota of food at each meal. They received water ad lib. from drinking bowls. Sodium chloride was supplied ad lib. to the animals in Expt 4 and one massive dose was offered to the animals in Expt 5 . Otherwise, no salt supplements were given to the animals. The amounts of $\mathrm{Na}, \mathrm{K}$, chloride and P supplied daily in each diet in Expt I are shown in Table $\mathbf{I}$. 
Expt $\mathrm{I}$. The rate of secretion of mixed saliva was measured when at least two of the four cows (A, B, C and D) were receiving one of the following diets: 40 lb of goodquality lucerne silage; $\mathrm{I} 4 \mathrm{lb}$ of medium-quality hay; $8 \mathrm{lb}$ of hay and $\mathrm{I} 2 \mathrm{lb}$ of dairy cubes; $12 \mathrm{lb}$ of flaked maize, $2 \mathrm{lb}$ of groundnut cake and $2 \mathrm{lb}$ of hay; a freshly cut mixture of cocksfoot and rye-grass supplying $12 \mathrm{lb}$ of dry matter daily. Four measurements were made daily with each animal and were repeated on 3 consecutive days. The first measurement was made before the morning meal ( $14 \mathrm{~h}$ after the previous meal) and the other three were made at $\mathrm{I}, 4$ and $8 \mathrm{~h}$ after the morning meal. It has been assumed that the measurement made $I_{4} \mathrm{~h}$ after the evening meal was similar in all respects to that which might have been made $14 \mathrm{~h}$ after the morning meal. Time was always measured from the beginning of eating. The water consumption was measured daily.

Expt 2. To ascertain the effects on saliva secretion of low $\mathrm{pH}$ values in the reticuloruminal contents, the $\mathrm{pH}$ of the contents in four cows $(\mathrm{A}, \mathrm{C}, \mathrm{D}$ and $\mathrm{E}$ ) was adjusted toward the lower extreme of the normal range by the addition of acetic acid. This adjustment was accomplished by removing about $50 \mathrm{lb}$ of contents, mixing into them $300 \mathrm{ml}$ of glacial acetic acid (diluted several times with water) and returning the mixture to the rumen, and was done once with each cow. Saliva secretion was measured $\frac{1}{2} h$ before the addition of acid, and $\frac{1}{2} h, I \frac{1}{2} h$ and $3 h$ after the addition. The experiment was confined to the latter half of the day to avoid that period when secretion rate changed rapidly (see p. 387 ).

Expt 3. This experiment was undertaken to investigate whether the act of eating per se had an important influence on the nature of the pattern of secretion. The act of eating was replaced in three cows (A, B and C) by stuffing the daily allowance of I $4 \mathrm{lb}$ hay into the ventral sac of the rumen through the fistula. The hay was chopped to approximately the same particle size as that attained during normal mastication of the same hay offered in the long state, and was placed in the ventral sac of the rumen to ensure that wetting should be as rapid as possible. The procedure of placing hay in the rumen has been described in detail elsewhere (Bailey \& Balch, 196r $a$ ). About 2 weeks after the beginning of this experiment, the secretion rate of mixed saliva was measured on 2 consecutive days with each cow at I, 4,8 and $\mathrm{I} 4 \mathrm{~h}$ after feeding.

Expt 4. The diets given in Expt I supplied different amounts of dry matter, and it is possible that the level of intake may have affected the rate of secretion of mixed saliva. To test this possibility and at the same time to exclude any complications that might result from the use of different diets, three cows (A, D and E) were given hay at three levels of intake and the rate of secretion of mixed saliva was measured 2 and $8 \mathrm{~h}$ after the beginning of feeding on 2 consecutive days. The levels of feeding were 6,12 and $\mathrm{I} 8 \mathrm{lb}$ hay daily. Six days were allowed for the change from one level to the next.

Since the $\mathrm{Na}$ content of bovine parotid saliva was reduced with $\mathrm{Na}$ depletion (Bailey \& Balch, 1961 $b$ ) and as most plant feeding materials have a low Na content, it is probable that the $\mathrm{Na}$ intake of the animals in the experiments described here would be sufficiently low with most rations (see Table I) to make the animal sensitive to $\mathrm{Na}$ loss. Accordingly, sodium chloride was supplied ad lib. throughout Expt 4 in order that the chemical composition of the saliva samples could be used as a standard 
against which to compare the chemical composition of the samples collected in the other experiments.

Expt 5. The results of Expt I were obtained over a period of more than a year. Had long-term trends occurred in the rate of salivary secretion they could have invalidated the differences in measurements with given animals on different diets when the measurements were made at intervals of several months. To determine whether long-term trends existed, the rate of salivary secretion was measured approximately twice weekly for more than 2 months in two cows (A and C) $4 \mathrm{~h}$ after they had eaten $7 \mathrm{lb}$ hay. The results of the chemical analysis of the saliva samples were also examined for long-term trends. Toward the end of the experiment each animal was given $500 \mathrm{~g}$ sodium chloride in the manger on one day $2 \mathrm{~h}$ before saliva collection began. The salt was readily consumed. This supplement was added to observe the effect of salt on the composition of the saliva.

\section{RESULTS \\ Rate of secretion}

Expt r. Mean values for the measurements of the rate of salivary secretion are shown in Fig. I.

A most striking uniformity was apparent in the mean daily pattern which was independent of the diet. The lowest rates of secretion were invariably found $\mathrm{I} h$ after the beginning of eating ( $10-30 \mathrm{~min}$ after the end of eating). Thereafter, they increased at 4 and $8 \mathrm{~h}$ to the high values measured $\mathrm{i} 4 \mathrm{~h}$ after eating. The grass diet invariably evoked the highest rate of secretion of saliva, and silage the lowest, with intermediate values for the other diets.

Comparison of Table 2 and Fig. I shows that there was no consistent relationship between the rate of secretion of saliva and the $\mathrm{pH}$ of the reticulo-ruminal contents.

Expt 2. Table 3 lists the rates of secretion of mixed saliva, the pH of the rumen fluid and the concentration of TVFA in the rumen fluid from each cow. The mean $\mathrm{pH}$ of the rumen fluid was lowered from 6.8 to 5.4 and the mean TVFA concentration was increased from 93 to $167 \mathrm{~m}$-equiv./l. by the addition of acetic acid to the rumen contents. The rates of secretion of mixed saliva were not related to either the $\mathrm{pH}$ or the concentration of TVFA in the rumen and the results obtained with cows A, D and E showed no consistent variations over the experimental period of $3 \frac{1}{2} \mathrm{~h}$. The mean rates of secretion in these three animals were $56,52,5^{6}$ and $54 \mathrm{ml} / \mathrm{min}$ at the four times of collection. Animal C, on the other hand, showed a progressive drop in the rate of secretion, which accounts for the slow decline observed in the mean values for all four cows in Table 3 .

Expt 3. The rate of secretion of mixed saliva $\mathrm{I} h$ after the animals had been given hay through the fistula was notably higher, relative to the rates measured at the succeeding times, than it was $\mathrm{I} h$ after normal feeding. Table 4 lists the mean rates of secretion measured in this experiment together with values for the same three cows when they consumed equal amounts of the same hay in Expt I. It has already been shown that, compared with normal feeding, administering foods through the fistula caused no change in the $\mathrm{pH}$ or chemical composition of rumen fluid (Bailey $\&$ Balch, 
1961 $a$ ), and it follows that the altered pattern of secretion measured in Expt 3 was independent of the chemical characteristics of the reticulo-ruminal digesta.

Expt 4. Table 5 gives the mean rates of secretion of mixed saliva in the three cows used in this experiment together with the $\mathrm{pH}$ and TVFA concentration of rumen fluid. In cows $\mathrm{A}$ and $\mathrm{E}$ there was a tendency for the rate of secretion of saliva to be smaller with increased intakes of hay. In cow D this tendency was apparent $2 \mathrm{~h}$ after feeding but not $8 \mathrm{~h}$ after feeding. The rate of secretion $8 \mathrm{~h}$ after the consumption of I $8 \mathrm{lb}$ hay was greater than that $8 \mathrm{~h}$ after the consumption of either 6 or $\mathrm{I} 2 \mathrm{lb}$ of hay. At the two lower levels of intake in cow $\mathrm{D}$, the rate of secretion $2 \mathrm{~h}$ after the beginning
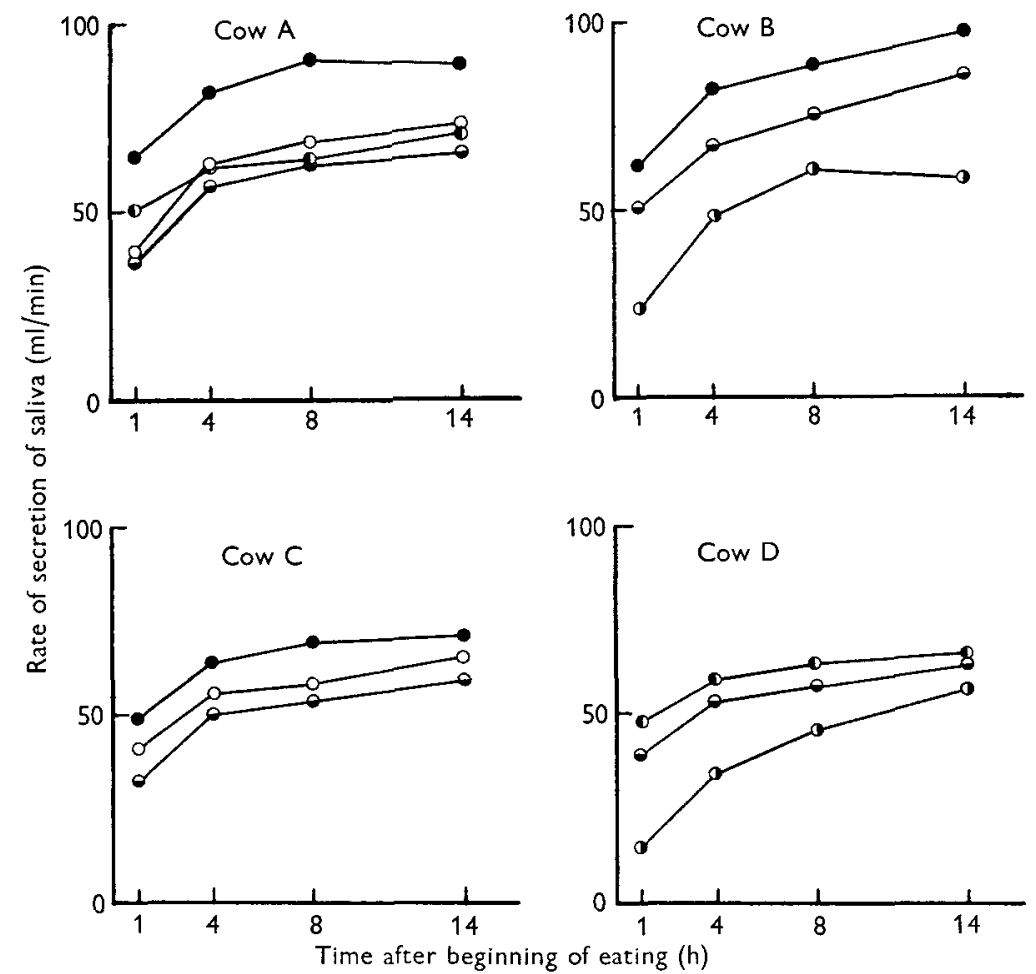

Fig. I. Expt 1. Mean rates of secretion of mixed saliva in the four cows at rest $1,4,8$ and I $4 \mathrm{~h}$ after the beginning of eating. Values are shown for diets of $40 \mathrm{lb}$ silage, $\mathrm{I} 4 \mathrm{lb}$ hay, $\theta$; $8 \mathrm{lb}$ hay and $\mathrm{I} 2 \mathrm{lb}$ dairy cubes, $\mathrm{O} ; 2 \mathrm{lb}$ hay, $\mathrm{I} 2 \mathrm{lb}$ flaked maize and $2 \mathrm{lb}$ groundnut cake, $\boldsymbol{O}$; and freshly cut grass,

of feeding was greater than that $8 \mathrm{~h}$ after feeding. This variation is contrary to the invariable pattern of secretion observed in this as in all the animals of Expt $\mathrm{I}$. There is, perhaps, some justification for assuming that the rates of secretion in cow D $8 \mathrm{~h}$ after the consumption of 6 and $\mathbf{1} 2 \mathrm{lb}$ of hay were anomalous, although no explanation of this situation can be offered.

Expt 5. The rates of secretion of saliva over the total period of the experiment are shown in Fig. 2. The values for cow A show no trends over the roo days during which measurements were made. Moreover, the variability was remarkably low. Although 
no trends were apparent in cow $\mathrm{C}$ also, the difference between individual measurements was large. Cow $\mathrm{C}$ was a nervous animal and her reaction to the taking of a blood sample shortly before the saliva sample may have contributed to this difference. Unfamiliar handling procedures are known to influence the rate of secretion by the parotid gland in sheep (Denton, 1957).

The exceedingly low rates of secretion noted on two occasions (Fig. 2), one for each animal, were probably due to the administration of $500 \mathrm{~g}$ of sodium chloride.

Table 2. Expt. I. Effect, in cows $A-D$, of diet on the $p H$ of rumen fluid $\mathrm{I}, 4,8$ and $\mathrm{I}_{4} h$ after the beginning of feeding, and on changes in the rate of secretion of mixed saliva during rest after feeding

(Values are means for 3 days)

\begin{tabular}{|c|c|c|c|c|c|c|c|}
\hline \multirow[b]{2}{*}{ Diet } & \multirow[b]{2}{*}{ Cow } & \multicolumn{4}{|c|}{$\mathrm{pH}$ of rumen fluid after } & \multirow{2}{*}{$\begin{array}{l}\text { Increase in } \\
\text { secretion rate } \\
\text { from the Ist to } \\
\text { the } 4_{\text {th }} \mathrm{h} \text { after } \\
\text { beginning of } \\
\text { feeding }(\mathrm{ml} / \mathrm{min})\end{array}$} & \multirow{2}{*}{$\begin{array}{l}\text { Ratio of the } \\
\text { mean rate of } \\
\text { saliva secretion } \\
\text { to the rate } \\
\text { with hay diet }\end{array}$} \\
\hline & & I h & $4 \mathrm{~h}$ & $8 \mathrm{~h}$ & $14 \mathrm{~h}$ & & \\
\hline \multirow[t]{2}{*}{ Silage } & $\begin{array}{l}\text { B } \\
\text { D }\end{array}$ & $\begin{array}{l}6 \cdot 70 \\
6 \cdot 84\end{array}$ & $\begin{array}{l}6 \cdot 77 \\
6 \cdot 95\end{array}$ & $\begin{array}{l}6 \cdot 78 \\
7 \cdot 07\end{array}$ & $\begin{array}{l}6 \cdot 91 \\
7 \cdot 22\end{array}$ & $\begin{array}{l}35 \\
43\end{array}$ & $\begin{array}{l}0.69 \\
0.70\end{array}$ \\
\hline & Mean & & & & & 一 & 0.70 \\
\hline \multirow[t]{2}{*}{ Hay } & $\begin{array}{l}\mathrm{A} \\
\mathrm{B} \\
\mathrm{C} \\
\mathrm{D}\end{array}$ & $\begin{array}{l}6 \cdot 61 \\
6 \cdot 58 \\
6 \cdot 86 \\
6 \cdot 64\end{array}$ & $\begin{array}{l}6 \cdot 77 \\
6 \cdot 68 \\
7 \cdot 02 \\
6 \cdot 82\end{array}$ & $\begin{array}{l}6 \cdot 76 \\
6 \cdot 76 \\
7 \cdot 16 \\
6 \cdot 93\end{array}$ & $\begin{array}{l}6 \cdot 84 \\
6 \cdot 78 \\
7 \cdot 18 \\
6 \cdot 88\end{array}$ & $\begin{array}{l}29 \\
35 \\
27 \\
24\end{array}$ & $\begin{array}{l}1.00 \\
1.00 \\
1.00 \\
1.00\end{array}$ \\
\hline & Mean & & & & & - & $I \cdot \infty$ \\
\hline Hay and dairy cubes & $\begin{array}{c}\mathrm{A} \\
\mathrm{C} \\
\text { Mean }\end{array}$ & $\begin{array}{l}6 \cdot 16 \\
6 \cdot 43\end{array}$ & $\begin{array}{l}6 \cdot 19 \\
6 \cdot 44\end{array}$ & $\begin{array}{l}6.45 \\
6.96\end{array}$ & $\begin{array}{l}6 \cdot 74 \\
7 \cdot 03\end{array}$ & $\begin{array}{l}33 \\
25 \\
-\end{array}$ & $\begin{array}{l}I \cdot 09 \\
I \cdot 15 \\
I \cdot I 2\end{array}$ \\
\hline \multirow[t]{2}{*}{$\begin{array}{l}\text { Hay, flaked maize and } \\
\text { groundnut cake }\end{array}$} & $\begin{array}{l}\mathrm{A} \\
\mathrm{D}\end{array}$ & $\begin{array}{l}5 \cdot 92 \\
6 \cdot 59\end{array}$ & $\begin{array}{l}5.72 \\
5.84\end{array}$ & $\begin{array}{l}6.53 \\
6.42\end{array}$ & $\begin{array}{l}7 \cdot 28 \\
6 \cdot 90\end{array}$ & $\begin{array}{l}20 \\
18\end{array}$ & $\begin{array}{l}I \cdot 09 \\
I \cdot I I\end{array}$ \\
\hline & Mean & & & & & - & $I \cdot I 0$ \\
\hline \multirow[t]{2}{*}{ Grass } & $\begin{array}{l}\mathbf{A} \\
\mathbf{B} \\
\mathbf{C}\end{array}$ & $\begin{array}{l}6 \cdot 73 \\
6 \cdot 85 \\
6 \cdot 88\end{array}$ & $\begin{array}{l}6.8 \mathrm{I} \\
6.80 \\
6.9 \mathrm{r}\end{array}$ & $\begin{array}{l}6.80 \\
6.83 \\
6.98\end{array}$ & $\begin{array}{l}6 \cdot 99 \\
7 \cdot 03 \\
7 \cdot 13\end{array}$ & $\begin{array}{l}25 \\
35 \\
23\end{array}$ & $\begin{array}{l}I \cdot 46 \\
I \cdot 20 \\
I \cdot 36\end{array}$ \\
\hline & Mean & & & & & - & $I \cdot 34$ \\
\hline
\end{tabular}

\section{Saliva composition}

Inorganic constituents. Tables 6 and 7 show the composition of the saliva samples collected in Expts I-3. In an animal subjected to any particular treatment, variations in the concentrations of the individual constituents were usually small. Except for the two cows consuming the diet of hay and dairy cubes, the mean concentrations of $\mathrm{Na}$, $\mathrm{K}$ and chloride showed considerable differences which were not consistently related to any particular animal or treatment. When cows $\mathrm{A}$ and $\mathrm{C}$ were given hay and dairy cubes the compositions of their saliva were virtually identical. The mean concentrations of bicarbonate and phosphate in the saliva samples were more uniform for all animals and all treatments than those of $\mathrm{Na}, \mathrm{K}$ or chloride. The composition of the 
samples of mixed saliva collected from the four cows in Expt 2 was affected little or not at all by the addition of acetic acid to the rumen (Table 7).

Table 8 shows the composition of mixed saliva from the three animals in Expt 4 . When the cows received $6 \mathrm{lb}$ of hay daily the concentrations of phosphate in the saliva were somewhat greater than at the higher levels of feeding; this was the only indication that the level of feeding influenced saliva composition. In general, the concentrations of all the constituents were very uniform and no large differences between animals were apparent. Bicarbonate was not determined in these samples.

Table 3. Expt 2. Effect of adding $300 \mathrm{ml}$ glacial acetic acid to the rumen contents on the rate of secretion of mixed saliva, the $p H$ of the rumen fluid and its total volatile fattyacid (TVFA) content in cows $A, C, D$ and $E$ at rest

\begin{tabular}{|c|c|c|c|c|}
\hline $\begin{array}{l}\text { Time after } \\
\text { addition } \\
\text { of acid } \\
\text { (h) }\end{array}$ & Cow & $\begin{array}{l}\text { Rate of } \\
\text { secretion } \\
\text { of saliva } \\
\text { (ml } / \mathrm{min})\end{array}$ & $\mathrm{pH}$ & $\begin{array}{c}\text { TVFA } \\
\text { (m-equiv./1.) }\end{array}$ \\
\hline \multirow[t]{5}{*}{$-\frac{1}{2}$} & A & 68 & $6 \cdot 78$ & 88 \\
\hline & C & 56 & $7 \cdot 24$ & 73 \\
\hline & D & 49 & $6 \cdot 47$ & 109 \\
\hline & $\mathrm{E}$ & 50 & $6 \cdot 69$ & IOI \\
\hline & Mean & 56 & $6 \cdot 80$ & 93 \\
\hline \multirow[t]{5}{*}{$\frac{1}{2}$} & A & $5 \mathrm{I}$ & 5.50 & I 50 \\
\hline & C & $4 \mathrm{I}$ & $5 \cdot 37$ & I 88 \\
\hline & $\mathrm{D}$ & 53 & 5.42 & $\mathbf{1}_{5}^{8}$ \\
\hline & $\mathrm{E}$ & 51 & $5 \cdot 38$ & I7 I \\
\hline & Mean & 49 & 5.42 & 167 \\
\hline \multirow[t]{5}{*}{$I \frac{1}{2}$} & A & 66 & 5.90 & 121 \\
\hline & C & 30 & 5.97 & 132 \\
\hline & D & 53 & $5 \cdot 89$ & 140 \\
\hline & $\mathrm{E}$ & 48 & $6 \cdot 28$ & I 37 \\
\hline & Mean & 49 & 6.01 & I 33 \\
\hline \multirow[t]{5}{*}{3} & A & $6 I$ & $6 \cdot 53$ & 112 \\
\hline & C & $2 I$ & $6 \cdot 60$ & 124 \\
\hline & D & $4 I$ & 6.37 & II 3 \\
\hline & $\mathbf{E}$ & 60 & $6 \cdot 6 I$ & I 14 \\
\hline & Mean & 46 & $6 \cdot 53$ & I 16 \\
\hline
\end{tabular}

Table 4. Expt 3. Rates of secretion, in cows A-C, of mixed saliva ( $\mathrm{ml} / \mathrm{min})$ during rest at I, 4, 8 and $\mathrm{I} 4 \mathrm{~h}$ after the beginning of normal feeding and after the administration of hay through the fistula

\begin{tabular}{|c|c|c|c|c|c|c|c|c|}
\hline \multirow[b]{3}{*}{ Cow } & \multicolumn{8}{|c|}{ Rate of secretion of mixed saliva $(\mathrm{ml} / \mathrm{min})$} \\
\hline & \multicolumn{4}{|c|}{ Hay eaten } & \multicolumn{4}{|c|}{ Hay placed in rumen } \\
\hline & I h & $4 \mathrm{~h}$ & $8 \mathrm{~h}$ & $\mathrm{I} 4 \mathrm{~h}$ & I $\mathrm{h}$ & $4 \mathrm{~h}$ & $8 \mathrm{~h}$ & $\mathrm{I} 4 \mathrm{~h}$ \\
\hline A & 37 & 57 & 64 & 66 & 61 & 66 & 70 & 78 \\
\hline $\mathrm{B}$ & 52 & 68 & 76 & 87 & 69 & 60 & 82 & 80 \\
\hline C & 32 & 50 & 53 & 59 & 44 & 39 & 38 & 42 \\
\hline Mean & 40 & $5^{8}$ & 64 & $7 x$ & 58 & 55 & 63 & 67 \\
\hline
\end{tabular}




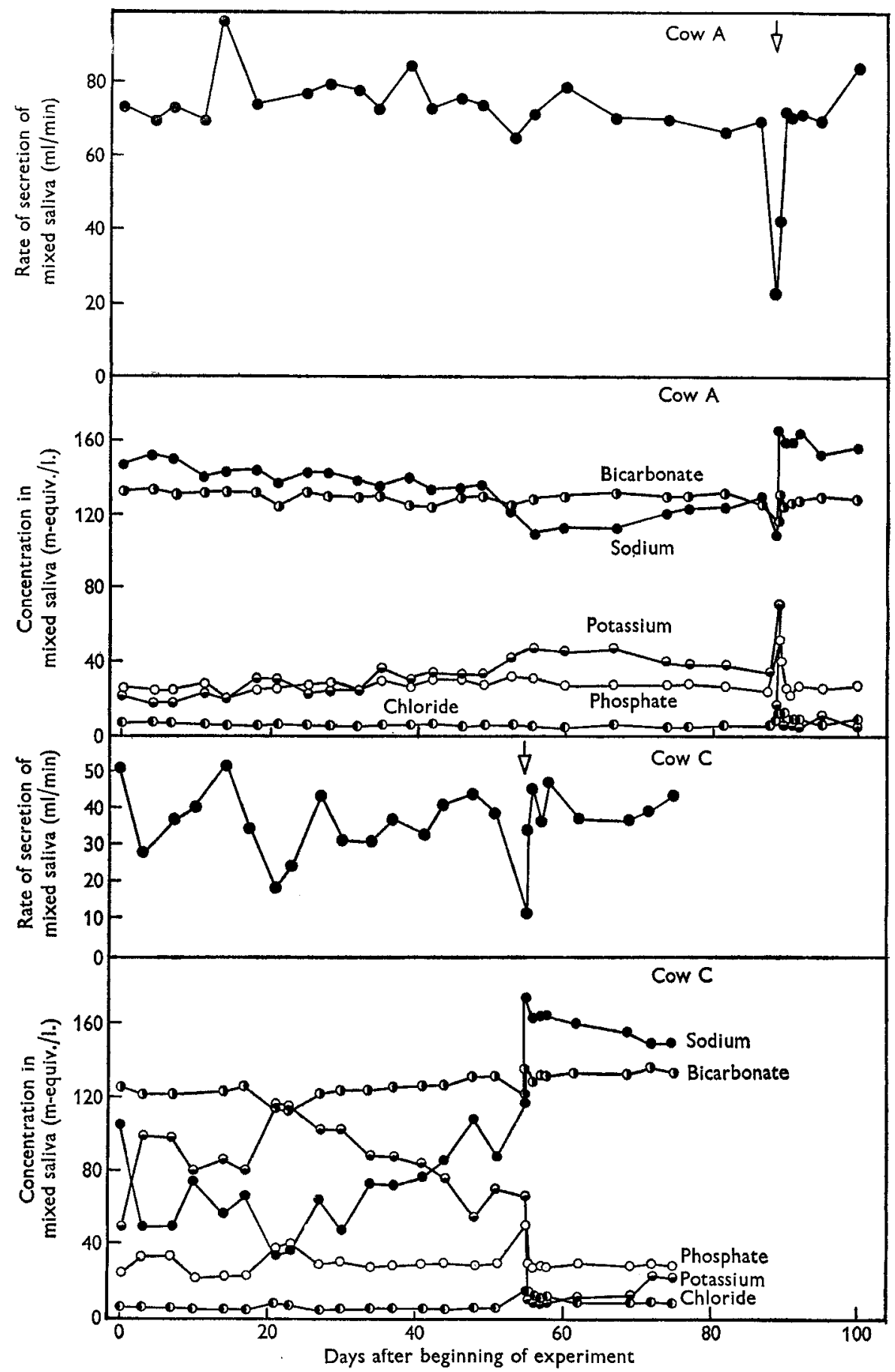

Fig. 2. Expt 5. Rates of secretion, in two cows, of mixed saliva collected $4 \mathrm{~h}$ after the beginning of feeding, and the concentrations of sodium, potassium, chloride, bicarbonate and phosphate in the saliva. The arrows show the single occasion when $500 \mathrm{~g}$ of sodium chloride were given. 
Table 5. Expt 4. Effect, in cows $A, D$ and $E$, of the level of hay intake on the mean rate of secretion of mixed saliva, the $p H$ of rumen fluid and its total volatile fatty-acid (TVFA) content during rest at 2 and $8 h$ after the beginning of feeding

\begin{tabular}{|c|c|c|c|c|c|c|c|c|c|c|}
\hline \multirow{3}{*}{$\begin{array}{l}\text { Daily } \\
\text { hay } \\
\text { intake } \\
\text { (lb) }\end{array}$} & \multirow[b]{3}{*}{ Cow } & \multirow{2}{*}{\multicolumn{3}{|c|}{$\begin{array}{l}\text { Saliva secretion } \\
\text { rate }(\mathrm{ml} / \mathrm{min})\end{array}$}} & \multicolumn{6}{|c|}{ Rumen fluid } \\
\hline & & & & & \multicolumn{3}{|c|}{$\mathrm{pH}$} & \multicolumn{3}{|c|}{ TVFA (m-equiv./1.) } \\
\hline & & $2 \mathrm{~h}$ & $8 \mathrm{~h}$ & Mean & $2 \mathrm{~h}$ & $8 \mathrm{~h}$ & Mean & $2 \mathrm{~h}$ & $8 \mathrm{~h}$ & Mean \\
\hline \multirow[t]{4}{*}{6} & A & 75 & 95 & 85 & $7 \cdot 1$ & $7 \cdot 3$ & $7 \cdot 2$ & 68 & 65 & 67 \\
\hline & D & 64 & 48 & 56 & $7 \cdot 2$ & $7 \cdot 3$ & $7 \cdot 3$ & 49 & 46 & 48 \\
\hline & $\mathrm{E}$ & $5 I$ & 58 & 54 & $7 \cdot 3$ & $7 \cdot 2$ & $7 \cdot 3$ & $5^{8}$ & 55 & 57 \\
\hline & Mean & 63 & 67 & 65 & $7 \cdot 2$ & $7 \cdot 3$ & $7 \cdot 3$ & $5^{8}$ & 55 & 57 \\
\hline \multirow[t]{4}{*}{12} & A & $5 \mathrm{I}$ & 67 & 59 & $7 \cdot 0$ & $6 \cdot 9$ & $7 \cdot 0$ & 76 & 87 & 82 \\
\hline & D & 53 & 43 & 48 & $6 \cdot 9$ & $7 \cdot 0$ & $7 \cdot 0$ & 86 & 80 & 83 \\
\hline & $\mathrm{E}$ & 46 & 53 & 49 & $7 \cdot I$ & $7 \cdot 1$ & $7 \cdot 1$ & $8 r$ & 68 & 75 \\
\hline & Mean & 50 & 54 & 52 & $7 \cdot 0$ & $7 \cdot 0$ & $7 \cdot 0$ & $8 I$ & 78 & 80 \\
\hline \multirow[t]{4}{*}{ I 8} & A & $5 \mathbf{I}$ & 64 & 57 & 7.0 & 7.0 & 7.0 & 96 & 94 & 95 \\
\hline & D & 49 & 61 & 55 & $6 \cdot 8$ & $6 \cdot 7$ & $6 \cdot 8$ & 9 I & $9 \mathrm{I}$ & 9 I \\
\hline & $\mathrm{E}$ & 34 & 50 & 42 & $6 \cdot 9$ & $6 \cdot 9$ & $6 \cdot 9$ & 89 & IOI & 95 \\
\hline & Mean & 45 & 58 & $5^{I}$ & $6 \cdot 9$ & $6 \cdot 9$ & $6 \cdot 9$ & 92 & 95 & 94 \\
\hline
\end{tabular}

Table 6. Expts $\mathrm{r}$ and 3. Effect of diet on the sodium, potassium, chloride, bicarbonate, phosphate, total nitrogen, urea nitrogen, dry-matter and ash contents and the $p H$ of mixed saliva from cows $A-D$ at rest

(Values are means for determinations at $\mathrm{I}, 4,8$ and $14 \mathrm{~h}$ after the beginning of feeding on each of 3 days)

\begin{tabular}{|c|c|c|c|c|c|c|c|c|c|c|c|}
\hline Diet & Cow & $\begin{array}{l}\text { Sodium } \\
(\mathrm{m}- \\
\text { equiv./1.) }\end{array}$ & $\begin{array}{l}\text { Potas- } \\
\text { sium } \\
\text { (m- } \\
\text { equiv./1.) }\end{array}$ & $\begin{array}{l}\text { Chloride } \\
\text { (m- } \\
\text { equiv./1.) }\end{array}$ & $\begin{array}{c}\mathrm{Bi}- \\
\text { carbonate } \\
(\mathrm{m}- \\
\text { equiv./1.) }\end{array}$ & $\begin{array}{l}\text { Phos- } \\
\text { phate } \\
\text { (m- } \\
\text { equiv./l.) }\end{array}$ & $\begin{array}{c}\text { Total } \\
\text { nitrogen } \\
\text { (mg/ } \\
100 \mathrm{ml})\end{array}$ & $\begin{array}{l}\text { Urea } \\
\text { nitrogen } \\
\text { (mg/ } \\
\text { 100 ml) }\end{array}$ & $\begin{array}{l}\text { Dry } \\
\text { matter } \\
(\%)\end{array}$ & $\begin{array}{l}\text { Ash } \\
(\%)\end{array}$ & $\mathrm{pH}$ \\
\hline \multirow[t]{2}{*}{ Silage* } & $\begin{array}{l}\text { B } \\
\text { D }\end{array}$ & $\begin{array}{l}109 \\
157\end{array}$ & $\begin{array}{r}49 \\
9\end{array}$ & $\begin{array}{r}5 \cdot 2 \\
10 \cdot 0\end{array}$ & $\begin{array}{l}120 \\
121\end{array}$ & $\begin{array}{l}32 \\
29\end{array}$ & $\begin{array}{l}\text { II } 6 \\
\text { I } 4 \cdot 4\end{array}$ & $\begin{array}{r}9 \cdot 8 \\
12 \cdot 3\end{array}$ & $\begin{array}{l}I \cdot 05 \\
I \cdot 00\end{array}$ & $\begin{array}{l}0.90 \\
0.86\end{array}$ & $\begin{array}{l}8 \cdot 4 \\
8 \cdot 4\end{array}$ \\
\hline & Mean & 133 & 29 & $7 \cdot 6$ & 121 & 31 & 13.0 & $I I \cdot I$ & $I \cdot 03$ & 0.88 & $8 \cdot 4$ \\
\hline \multirow[t]{2}{*}{$\begin{array}{l}\text { Hay (given } \\
\text { normally) }\end{array}$} & $\begin{array}{l}\mathrm{A} \\
\mathrm{B} \\
\mathrm{C} \\
\mathrm{D}\end{array}$ & $\begin{array}{r}89 \\
\text { r58 } \\
\text { r53 } \\
106\end{array}$ & $\begin{array}{r}63 \\
5 \\
11 \\
46\end{array}$ & $\begin{array}{l}3 \cdot 0 \\
8 \cdot 4 \\
7 \cdot 6 \\
4 \cdot 2\end{array}$ & $\begin{array}{l}122 \\
126 \\
127 \\
126\end{array}$ & $\begin{array}{l}21 \\
23 \\
22 \\
23\end{array}$ & $\begin{array}{l}6 \cdot 0 \\
4 \cdot 5 \\
3 \cdot 3\end{array}$ & $\begin{array}{l}4 \cdot 4 \\
3 \cdot 2 \\
2 \cdot 7 \\
2 \cdot 1\end{array}$ & $\begin{array}{l}x \cdot 07 \\
0.97 \\
0.97 \\
I \cdot 04\end{array}$ & $\begin{array}{l}0.89 \\
0.86 \\
0.86 \\
0.89\end{array}$ & $\begin{array}{l}8 \cdot 4 \\
8 \cdot 5 \\
8 \cdot 5 \\
8 \cdot 3\end{array}$ \\
\hline & Mean & 126 & $3 I$ & $5 \cdot 8$ & 125 & 22 & - & $3 \cdot I$ & $I \cdot O I$ & 0.88 & $8 \cdot 4$ \\
\hline \multirow[t]{2}{*}{$\begin{array}{l}\text { Hay (given } \\
\text { through } \\
\text { fistula) }+\end{array}$} & $\begin{array}{l}\mathrm{A} \\
\mathrm{B} \\
\mathrm{C}\end{array}$ & $\begin{array}{r}107 \\
133 \\
75\end{array}$ & $\begin{array}{l}61 \\
36 \\
89\end{array}$ & $\begin{array}{l}3 \cdot 8 \\
6 \cdot 0 \\
3 \cdot 9\end{array}$ & $\begin{array}{l}123 \\
121 \\
\text { I } 16\end{array}$ & $\begin{array}{l}20 \\
23 \\
27\end{array}$ & $\begin{array}{l}- \\
- \\
-\end{array}$ & $\overline{-}$ & $\overline{-}$ & $\overline{-}$ & $\begin{array}{l}8 \cdot 4 \\
8 \cdot 4 \\
8 \cdot 4\end{array}$ \\
\hline & Mean & 105 & 62 & $4 \cdot 6$ & 120 & 23 & - & - & - & $\cdots$ & $8 \cdot 4$ \\
\hline \multirow[t]{2}{*}{$\begin{array}{l}\text { Hay and } \\
\text { dairy cubes* }\end{array}$} & $\begin{array}{l}\mathrm{A} \\
\mathrm{C}\end{array}$ & $\begin{array}{l}164 \\
164\end{array}$ & $\begin{array}{l}4 \\
4\end{array}$ & $\begin{array}{l}8 \cdot x \\
6 \cdot 3\end{array}$ & $\begin{array}{l}124 \\
125\end{array}$ & $\begin{array}{l}30 \\
28\end{array}$ & $\begin{array}{l}12 \cdot 0 \\
12 \cdot 4\end{array}$ & $\begin{array}{l}10.6 \\
10.4\end{array}$ & $\begin{array}{l}1.01 \\
1.04\end{array}$ & $\begin{array}{l}0.88 \\
0.89\end{array}$ & $\begin{array}{l}8 \cdot 5 \\
8 \cdot 4\end{array}$ \\
\hline & Mean & I64 & 4 & $7 \cdot 2$ & 125 & 29 & $12 \cdot 2$ & 10.5 & $I \cdot 03$ & 0.89 & $8 \cdot 5$ \\
\hline \multirow[t]{2}{*}{$\begin{array}{l}\text { Hay, flaked maize } \\
\text { and groundnut cake* }\end{array}$} & $\begin{array}{l}\mathrm{A} \\
\mathrm{D}\end{array}$ & $\begin{array}{l}140 \\
156\end{array}$ & $\begin{array}{r}23 \\
9\end{array}$ & $\begin{array}{l}6 \cdot 6 \\
9 \cdot 0\end{array}$ & $\begin{array}{l}122 \\
121\end{array}$ & $\begin{array}{l}29 \\
28\end{array}$ & $\begin{array}{r}\text { I } 1 \cdot 8 \\
9 \cdot \mathbf{I}\end{array}$ & $\begin{array}{l}9 \cdot 0 \\
7 \cdot 6\end{array}$ & $\begin{array}{l}I .04 \\
I .00\end{array}$ & $\begin{array}{l}0.92 \\
0.88\end{array}$ & $\begin{array}{l}8 \cdot 4 \\
8 \cdot 4\end{array}$ \\
\hline & Mean & I 48 & 16 & $7 \cdot 8$ & 122 & 29 & 10.5 & $8 \cdot 3$ & $\mathrm{I} \cdot 02$ & 0.90 & $8 \cdot 4$ \\
\hline \multirow[t]{2}{*}{ Grass* } & $\begin{array}{l}\mathrm{A} \\
\mathrm{B} \\
\mathrm{C}\end{array}$ & $\begin{array}{l}150 \\
153 \\
125\end{array}$ & $\begin{array}{l}r_{4} \\
14 \\
39\end{array}$ & $\begin{array}{l}8 \cdot 3 \\
7 \cdot 0 \\
4 \cdot 6\end{array}$ & $\begin{array}{l}126 \\
121 \\
125\end{array}$ & $\begin{array}{l}22 \\
30 \\
24\end{array}$ & $\begin{array}{l}- \\
-\end{array}$ & $\begin{array}{l}7 \cdot 3 \\
6 \cdot 8 \\
5 \cdot 0\end{array}$ & $\begin{array}{l}0.98 \\
I \cdot 02 \\
\mathrm{I} \cdot 04\end{array}$ & $\begin{array}{l}0.87 \\
0.90 \\
0.93\end{array}$ & $\begin{array}{l}8 \cdot 5 \\
8 \cdot 3 \\
8 \cdot 4\end{array}$ \\
\hline & Mean & 143 & 22 & $6 \cdot 6$ & I 24 & 25 & - & 6.7 & I'OI & 0.90 & 8.4 \\
\hline
\end{tabular}

\footnotetext{
* Expt r. + Expt 3 .
} 
The composition of the mixed saliva collected from cows A and C in Expt 5 is shown in Fig. 2. Large fluctuations in the $\mathrm{Na}$ and $\mathrm{K}$ concentrations were revealed, especially in cow $\mathrm{C}$. In cow $\mathrm{A}$ there was a tendency for the $\mathrm{Na}$ and chloride concentrations to fall and the $\mathrm{K}$ concentration to increase throughout the period of the experiment before the administration of $500 \mathrm{~g}$ of sodium chloride. The administration

Table 7. Expt 2. Effect of adding $300 \mathrm{ml}$ glacial acetic acid to the rumen contents on the sodium, potassium, chloride, bicarbonate, phosphate, total nitrogen and urea nitrogen contents and the $p H$ of mixed saliva from cows $A, C, D$ and $E$ at rest

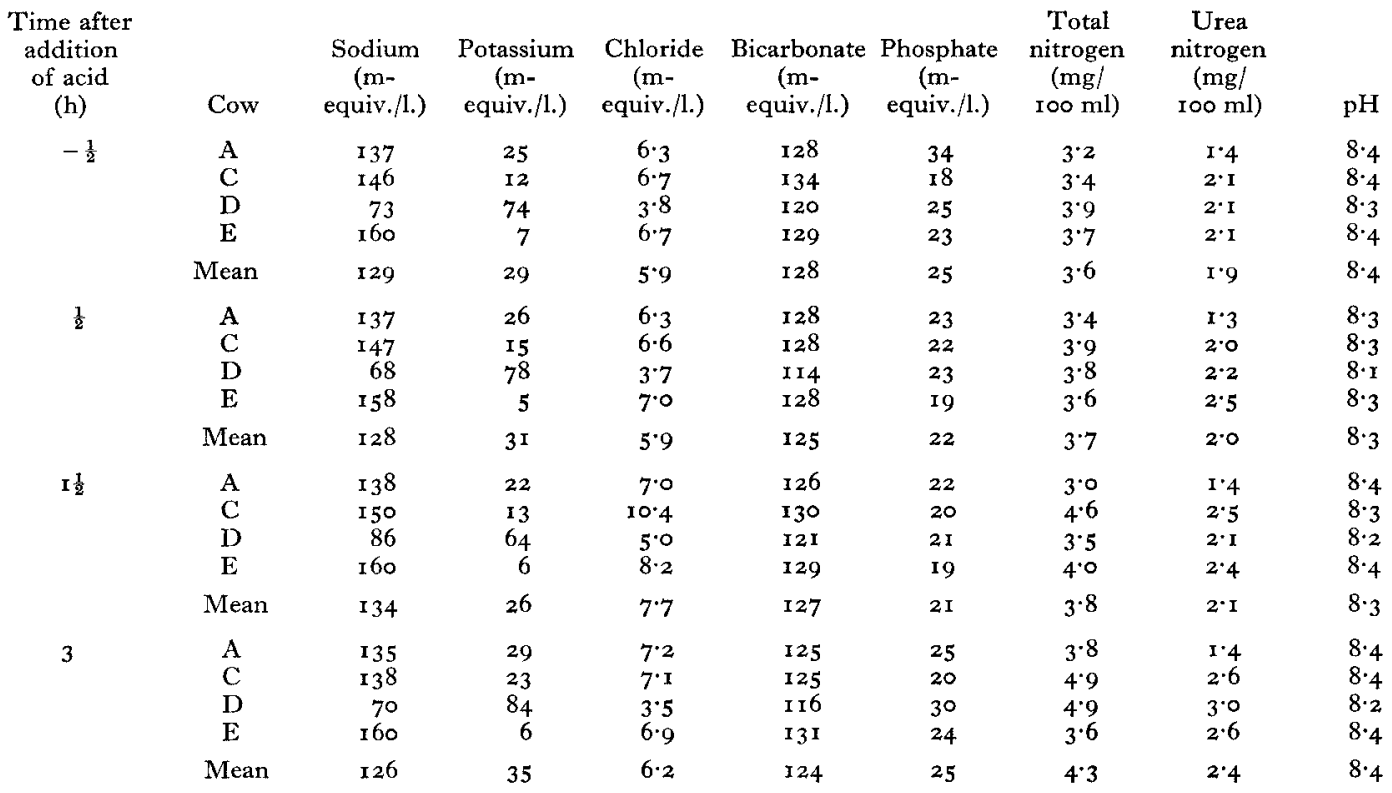

Table 8. Expt 4. Effect of the level of hay intake on the sodium, potassium, chloride, phosphate, total nitrogen, urea nitrogen, dry-matter and ash contents and the $p H$ of mixed saliva in cows $A, D$ and $E$ at rest

(Values are means for samples collected during rest at 2 and $8 \mathrm{~h}$ after the beginning of feeding)

\begin{tabular}{|c|c|c|c|c|c|c|c|c|c|}
\hline $\begin{array}{l}\text { Daily } \\
\text { hay } \\
\text { intake } \\
\text { (lb) }\end{array}$ & Cow & $\begin{array}{l}\text { Sodium } \\
\text { (m- } \\
\text { equiv./1.) }\end{array}$ & $\begin{array}{l}\text { Potassium } \\
\text { (m- } \\
\text { equiv./1.) }\end{array}$ & $\begin{array}{l}\text { Chloride } \\
\text { (m- } \\
\text { equiv./l.) }\end{array}$ & $\begin{array}{c}\text { Phosphate } \\
\text { (m- } \\
\text { equiv./1.) }\end{array}$ & $\begin{array}{c}\text { Total } \\
\text { nitrogen } \\
(\mathrm{mg} / \\
\text { roo ml) }\end{array}$ & $\begin{array}{c}\text { Urea } \\
\text { nitrogen } \\
\text { (mg/ } \\
\text { roo ml) }\end{array}$ & $\begin{array}{c}\text { Dry } \\
\text { matter } \\
(\%)\end{array}$ & $\begin{array}{l}\text { Ash } \\
(\%)\end{array}$ \\
\hline 6 & $\begin{array}{l}\text { A } \\
\text { D } \\
\text { E }\end{array}$ & $\begin{array}{l}164 \\
166 \\
162\end{array}$ & $\begin{array}{l}4 \cdot 1 \\
4 \cdot 9 \\
6 \cdot 2\end{array}$ & $\begin{array}{l}7 \cdot 2 \\
8.0 \\
6 \cdot 7\end{array}$ & $\begin{array}{l}32 \\
33 \\
29\end{array}$ & $\begin{array}{l}4.4 \\
5.8 \\
6.8\end{array}$ & $\begin{array}{l}2 \cdot 8 \\
4 \cdot 4 \\
5 \cdot 0\end{array}$ & $\begin{array}{l}1 \cdot 00 \\
1 \cdot 04 \\
1 \cdot 02\end{array}$ & $\begin{array}{l}0.89 \\
0.89 \\
0.87\end{array}$ \\
\hline & Mean & 164 & $5 \cdot I$ & $7 \cdot 3$ & $3 \mathrm{I}$ & 577 & $4 \cdot I$ & $I \cdot 02$ & 0.88 \\
\hline 12 & $\begin{array}{l}\mathrm{A} \\
\mathrm{D} \\
\mathrm{E}\end{array}$ & $\begin{array}{l}156 \\
\times 53 \\
159\end{array}$ & $\begin{array}{r}8.6 \\
10 \cdot 2 \\
5.0\end{array}$ & $\begin{array}{l}7.4 \\
8.6 \\
7.4\end{array}$ & $\begin{array}{l}23 \\
22 \\
28\end{array}$ & $\begin{array}{l}4.7 \\
7 \circ 0 \\
5.1\end{array}$ & $\begin{array}{l}2 \cdot 9 \\
4.8 \\
3 \cdot 6\end{array}$ & $\begin{array}{l}0.97 \\
0.99 \\
0.98\end{array}$ & $\begin{array}{l}0.85 \\
0.86 \\
0.85\end{array}$ \\
\hline & Mean & 156 & $7 \cdot 6$ & $7 \cdot 4$ & 24 & $5 \cdot 6$ & $3 \cdot 8$ & 0.98 & 0.85 \\
\hline 18 & $\begin{array}{l}A \\
D \\
E\end{array}$ & $\begin{array}{l}162 \\
164 \\
161\end{array}$ & $\begin{array}{l}5 \cdot 6 \\
5.4 \\
5 \cdot 7\end{array}$ & $\begin{array}{l}6 \cdot 5 \\
7 \cdot 1 \\
6 \cdot 4\end{array}$ & $\begin{array}{l}22 \\
24 \\
25\end{array}$ & $\begin{array}{l}4.5 \\
6.3 \\
5.7\end{array}$ & $\begin{array}{l}3 \cdot 2 \\
4 \cdot 5 \\
3 \cdot 8\end{array}$ & $\begin{array}{l}0.99 \\
0.98 \\
r .00\end{array}$ & $\begin{array}{l}0.87 \\
0.86 \\
0.87\end{array}$ \\
\hline & Mean & 163 & $5 \cdot 6$ & 6.7 & 24 & 5.5 & $3 \cdot 8$ & 0.99 & 0.87 \\
\hline
\end{tabular}


of the sodium chloride led to rapid and profound adjustments in the concentrations of the ions, especially of $\mathrm{Na}, \mathrm{K}$ and chloride. After the adjustment the concentrations of all the ions resembled very closely those in the saliva collected from the three cows in Expt 4 (Table 8).

Nitrogenous constituents. The contents of both total $\mathrm{N}$ and urea $\mathrm{N}$ in saliva were dependent to a large extent on the nature of the diet, values being low when the animals consumed hay, intermediate when they consumed grass or hay and flaked maize, and high when they consumed silage or hay and dairy cubes. Urea $\mathrm{N}$ constituted

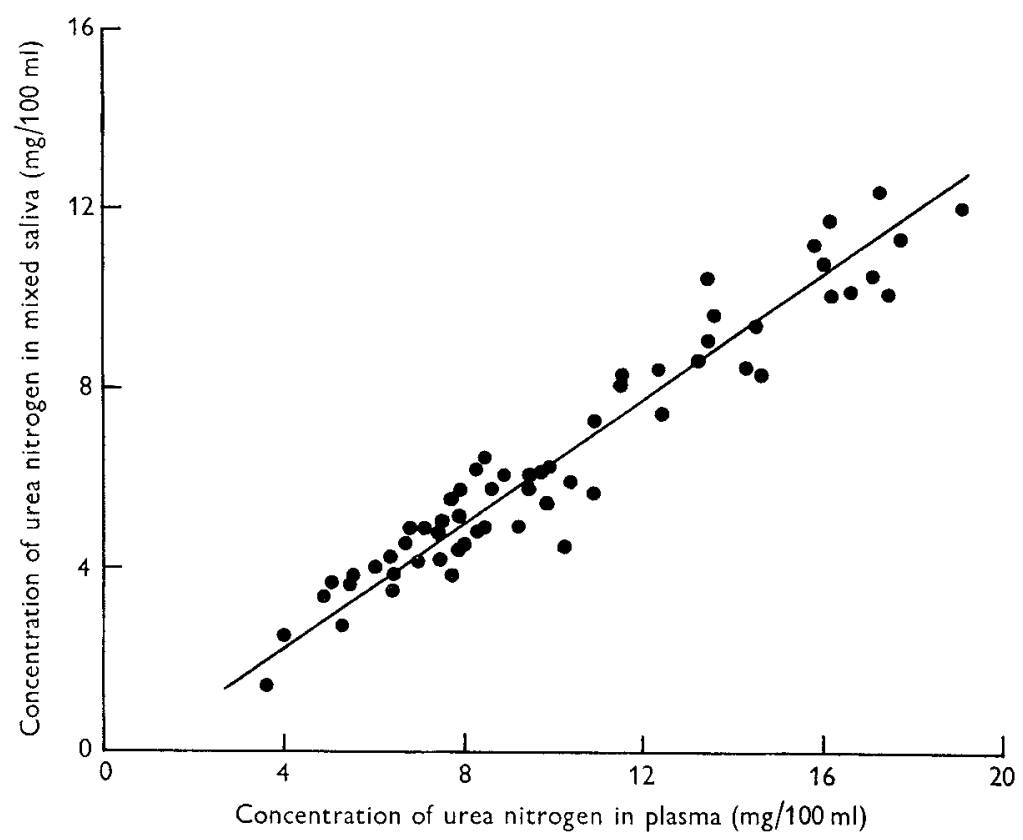

Fig. 3. Relationship, in four cows, between the concentrations of urea $\mathrm{N}$ in the mixed saliva and in blood plasma collected at the same ( $\pm 15 \mathrm{~min})$ time.

a large proportion of the total $\mathrm{N}$ in saliva. In Expt $\mathrm{I}$, the urea $\mathrm{N}$ accounted for 85.5 , $62 \cdot 9,86 \cdot 8$ and $79 \cdot 6 \%$ of the total $\mathrm{N}$ in the mixed saliva of the cows consuming the silage, hay, hay and dairy cubes, and hay and flaked-maize diets, respectively. The overall mean value for all cows and rations was $77 \cdot 2 \%$ of the total $\mathrm{N}$. The differences in values with the different diets were due to increases in the urea content of saliva which were not accompanied by commensurate increases in non-urea $\mathrm{N}$.

The plasma from the samples of jugular venous blood taken in Expts $\mathrm{I}$ and 5 was analysed for urea and the relationship between the values so obtained and the urea concentrations in the saliva samples collected at the same time is shown in Fig. 3. The urea content of saliva was about $65 \%$ of that in the plasma, with plasma values ranging from 4 to $19 \mathrm{mg}$ urea $\mathrm{N} / \mathrm{I} 00 \mathrm{ml}$ plasma.

Dry matter and ash. The dry-matter and ash contents of mixed saliva showed only small variations and no relationship was discerned between these values and any treatment, animal or experiment. The mean values for all the samples were $\mathrm{I} \cdot 02 \% \mathrm{dry}$ matter and $0.89 \%$ ash. 


\section{DISCUSSION}

The experiments have provided information about the rate of secretion and composition of mixed saliva, collected at the cardia, in resting cattle. In discussing the values obtained our primary concern is the extent to which either the rate of secretion or the composition appeared to vary in response to changing conditions in the reticulorumen.

\section{Rate of secretion of mixed saliva}

During the collection of a swallow of saliva the small rubber bag was applied for only a few seconds to the area surrounding the cardia. Care was taken to make the application brief and light since preliminary experiments (Bailey, I957, unpublished results) had shown that the rates of secretion in two cows were increased from 6I and $63 \mathrm{ml} \mathrm{saliva} / \mathrm{min}$ with this technique to I I I and I I $6 \mathrm{ml}$ saliva/min respectively when a large bag with a rigid rim was held firmly against the cardia for 5-10 min.

Care was also taken to leave undisturbed the contents of the reticulum, and it is thought that the prior removal of part of the digesta from the rumen, in order to expose the cardia, had little effect on the rate at which saliva was secreted. It certainly seems likely that any abnormality of flow so induced would be less than might be expected to result from techniques using oesophageal cannulas (Colin, I886) and the aspiration of saliva trapped in the oesophagus by inflated catheters, as has been used in both cattle (Cunningham, 1958) and sheep (Hydén, 1958). It has been shown that stimulation of tactile receptors in the oesophagus influences the rate of secretion of parotid saliva (Clark \& Weiss, 1952; Ash \& Kay, 1959). We attach considerable importance to the fact that our results were obtained with cows that, apart from cow $\mathrm{C}$, were placid, comfortable and undisturbed.

The rate of secretion of mixed saliva was invariably least shortly after a meal and increased with time after the meal. There was, therefore, a remarkable similarity between this pattern of secretion of mixed saliva and the pattern of secretion of parotid saliva (Bailey \& Balch, $196 \mathrm{r} b$ ). This finding suggests that the factors that gave rise to the pattern of secretion in the parotid were also involved in establishing it in the mixed saliva, and confirms the probability that the mixed saliva largely contains parotid saliva or saliva from other glands with similar secretory properties (Kay, I960).

The lowest rates of secretion of mixed saliva occurred at times when chemical and physical stimulation in the reticulo-rumen would be maximal, or nearly so, as a result of the ingestion and fermentation of the food. Further when, in Expt 2, the mean $\mathrm{pH}$ of the rumen fluid was lowered from 6.8 to 5.4 and the TVFA concentration was raised from 93 to $167 \mathrm{~m}$-equiv./1. as a result of adding acetic acid to the rumen contents, no consistent changes resulted in the secretion of the mixed saliva. These observations were unexpected since it was logical to suppose that tactile receptors located in the reticulum would be stimulated and the rate of secretion of saliva increased after a meal. Indeed, Weiss (1953) suggested that saliva secretion was enhanced after the ingestion of food, owing to the tactile stimulation of receptors in the stomach. Further, in view of the importance of buffers in maintaining a fairly 
stable rumen $\mathrm{pH}$ (McManus, I959) it seemed reasonable to suppose that alterations in the acidity of the rumen contents would influence the secretion of saliva.

The effect on salivary secretion of tactile stimulation of the sensitive areas of the oesophagus and reticulum has been established beyond reasonable doubt. It is a matter of conjecture as to why measurable increases of salivary secretion were not observed after the ingestion of food in the experiments described here. Possibly the effectiveness of tactile stimulation shortly after a meal was inhibited by some factors whose nature is not known. Both in these experiments and in those concerned with the secretion of parotid saliva (Bailey \& Balch, I96I $b$ ) the experimental animals were fed twice daily and the inhibition of the effects of tactile stimulation may have been initiated by the act of eating per se. This possibility is supported by the results of Expt 3, in which three cows received all their food through the fistula for $2 \frac{1}{2}$ weeks. When salivary secretion was measured towards the end of that period it was found that the rate did not fall as low after a meal of hay given through the fistula as it did in the same cows after normal feeding (Table 4). This finding suggests that the degree of inhibition is not related to the amount of digesta in the rumen but, as discussed previously (Bailey \& Balch, I96I $b$ ), does not preclude the possibility that during eating the sensory nerve endings tire. Whatever causes were responsible for establishing the pattern of secretion of mixed saliva during periods of rest, it seems clear that this pattern was an integral part of the response of the animal to the feeding routine.

Table 9. Rate of secretion of mixed saliva collected by means of a large rubber bag during rest at 2 and $\mathrm{I}_{7} h$ after the beginning of feeding in cows $A$ and $B$ (Bailey, 1957)

\begin{tabular}{lccc}
\multicolumn{1}{c}{ Diet } & Cow & $\begin{array}{c}\text { Rate of secretion of } \\
\text { saliva } 2 \mathrm{~h} \text { after } \\
\text { beginning of } \\
\text { feeding }(\mathrm{ml} / \mathrm{min})\end{array}$ & $\begin{array}{c}\text { Increase in secretion } \\
\text { rate from } \\
\text { 2 to I7 h after } \\
\text { beginning of } \\
\text { feeding }(\mathrm{ml} / \mathrm{min})\end{array}$ \\
Hay & $\mathrm{A}$ & 86 & 30 \\
Hay and dairy cubes & $\mathrm{A}$ & $\mathrm{II6}$ & 30 \\
Hay and dairy cubes & $\mathrm{B}$ & $\mathrm{II9}$ & $\mathbf{2 2}$ \\
Grass & $\mathrm{B}$ & $\mathrm{I25}$ & 36
\end{tabular}

With different diets the cows secreted different amounts of mixed saliva while they were resting but, in Expt 1 , the increase in the rate of secretion of saliva from the Ist to the $14^{\text {th }} \mathrm{h}$ after feeding was remarkably constant in each cow, irrespective of diet (Table 2). Further, in the preliminary experiment (Bailey, I957, unpublished) referred to above, saliva was collected in a large bag held firmly over the cardia, and the rates of secretion (Table 9), although faster than with the usual method of collection, increased by the same increments over the period from the 2 nd to the $I 7$ th $h$ after feeding. Accordingly it appears that the characteristics of the diets which evoked the differences in the rate of salivary secretion in Expt I were simply superimposed on a pattern of decreasing inhibition during the periods of rest after a meal.

It is clear from Tables 2 and 9 that the grass diet invariably evoked the highest rate of secretion of saliva, silage evoked the lowest rate and values for the other diets were 
intermediate. It would be of particular interest to know what characteristics of the various diets led to these differences in the secretion of saliva. The amount of digesta seems unlikely to have been responsible, because the emptying of the rumen before collection of the saliva will have eliminated many differences. The fibrous and abrasive properties of the digesta in the reticulo-rumen were clearly not responsible, because the highest rates of secretion were observed with grass, which produced the softest and most spongy digesta. Moreover, differences in the acidity of the rumen contents had no consistent relationship to the rate of secretion of mixed saliva.

These experiments did not reveal, therefore, the dietary characteristics responsible for the differences in rate of saliva secretion. The possible effect of the degree of fill and nature of the contents of the lower gut should not be overlooked, however, especially in view of the results of Expt 4.

\section{Composition of mixed saliva}

Inorganic constituents. Values obtained by analysing some 284 samples of mixed saliva produced at rates of secretion ranging from 12 to $\mathrm{I} I 0 \mathrm{ml} / \mathrm{min}$ are summarized in Tables $6-8$ and in Fig. 2. When saliva was secreted at rates greater than about $30 \mathrm{ml} / \mathrm{min}$ the concentrations of both bicarbonate and phosphate in the fluids showed only very small fluctuations; the mean concentrations were similar for each cow

Table 10. Mean values with their standard errors (m-equiv./l.) for concentrations of bicarbonate and phosphate in mixed saliva secreted at flow rates greater than $30 \mathrm{ml} / \mathrm{min}$ in cows $A-E$ at rest

$\begin{array}{cccc}\text { Cow } & \begin{array}{c}\text { No. of } \\ \text { samples }\end{array} & \text { Bicarbonate } & \text { Phosphate } \\ \text { A } & 97 & 125 \pm 0.43 & 25 \pm 0.45 \\ \text { B } & 41 & 123 \pm 0.52 & 26 \pm 0.66 \\ \text { C } & 66 & 125 \pm 0.61 & 27 \pm 0.68 \\ \text { D } & 48 & 123 \pm 1.03 & 26 \pm 0.67 \\ \text { E } & 16 & 129 \pm 0.65 & 25 \pm 0.82 \\ \text { Mean } & & 125 & 26\end{array}$

(Table 10) and no consistent effects of the treatments could be discerned. With decrease of secretion rate below $30 \mathrm{ml} / \mathrm{min}$, the bicarbonate concentrations decreased and the phosphate concentrations increased. These changes were essentially like those that occurred in the bicarbonate and phosphate concentrations of parotid saliva secreted at low rates of flow in sheep (Coats \& Wright, I957) and in a steer (Bailey \& Balch, I96 $b$ ). With the steer there was a direct linear relationship between the rate of secretion of parotid saliva (as $\mathrm{ml} / \mathrm{min}$ ) and the rate of secretion of the ions (as m-equiv./min). The observations with the steer suggested that the composition of additional amounts of saliva, secreted in a given time at rates greater than the lowest rate measured, were of constant composition if it is assumed that the basal flow is secreted at a standard speed and composition. The same conclusion may be reached for the bicarbonate and phosphate ions in these experiments, for the secretion rates of these two ions in mixed saliva were linearly related to the rate of salivary secretion. For the bicarbonate ion, the value of the slope was $130 \mathrm{~m}$-equiv./1., which corresponds 
very closely to the value of the slope for the same ion in bovine parotid saliva (I3I m-equiv./l., Bailey \& Balch, 1961 $b$ ). This observation suggests that the secreting structures which elaborated each type of fluid were very similar and the same conclusion follows from a consideration of the secretory characteristics of the phosphate ion. It is reasonable to conclude, therefore, that the samples of mixed saliva comprised largely parotid (or parotid-like) components.

$\mathrm{Na}$ and $\mathrm{K}$ together constitute about $98 \%$ of the cations of the mixed saliva of ruminants (McDougall, 1948; Phillipson \& Mangan, 1959) and a decrease or increase

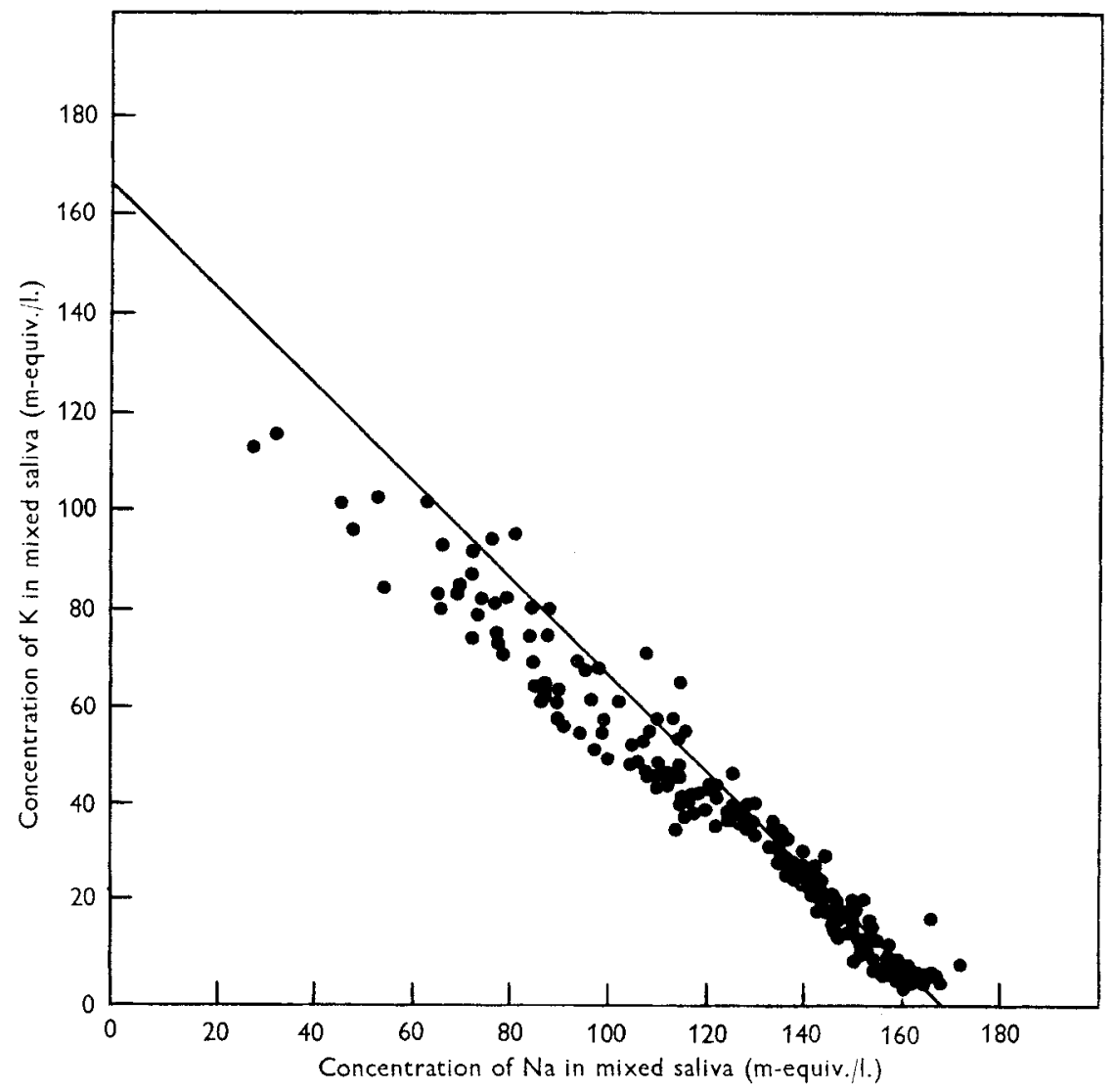

Fig. 4. Relationship, in five cows, between the concentrations of sodium and potassium in mixed saliva. The straight line joins points at which the sum of the $\mathrm{Na}$ and $\mathrm{K}$ concentrations was $166 \mathrm{~m}$-equiv. $/ 1$.

in Na content is likely to be accompanied by a commensurate increase or decrease in that of $\mathrm{K}$. In the experiments described here the total concentrations of $\mathrm{Na}$ and $\mathrm{K}$ in saliva tended to be about $166 \mathrm{~m}$-equiv./1., decreasing by a small extent when the $\mathrm{Na}$ concentration fell below about $\mathrm{I} 20 \mathrm{~m}$-equiv./1. (Fig. 4). Moreover when the $\mathrm{Na}$ concentration increased above about $\mathrm{I} 64 \mathrm{~m}$-equiv./1., the $\mathrm{K}$ concentration did not decrease below the mean plasma $\mathrm{K}$ concentration, and the sum of the concentrations of $\mathrm{Na}$ and $\mathrm{K}$ increased accordingly above $\mathrm{I} 66 \mathrm{~m}$-equiv./1. The salivary glands were 
apparently incapable, at this level, of transferring water to the saliva without $\mathrm{K}$. Within values for any animal receiving a given diet in Expt $\mathrm{I}$, variations in the content of $\mathrm{Na}, \mathrm{K}$ and chloride were small (Table 6), but the contents of these ions varied considerably when the same animal received different diets. For example, at equivalent rates of secretion $(62 \mathrm{ml} / \mathrm{min})$ the mean $\mathrm{Na}$ concentrations in the mixed saliva of cow $\mathrm{A}$ were $87 \mathrm{~m}$-equiv./1. with hay and $\mathrm{I}_{3} \mathrm{~m}$-equiv./1. with hay and dairy cubes; the corresponding concentrations of $\mathrm{K}$ were 62 and $4 \mathrm{~m}$-equiv./1. respectively. It is not clear, however, why these variations occurred, although with the vegetable diets used, a shortage of Na seems more likely than a shortage of K. A shortage of dietary $\mathrm{Na}$ would probably lead to lowering of $\mathrm{Na}$ concentrations in the parotid saliva just as they are lowered when (Denton, $\mathrm{r}_{95}$ ) the $\mathrm{Na}$ lost in the fluid from a parotid fistula is not replaced.

It is probable that in Expt I Na-retaining mechanisms were induced in the animals to a greater or less degree with all diets except that of hay and dairy cubes. With sodium chloride added ad lib. to a diet of hay (Expt 4) the mean concentration of $\mathrm{Na}$ in the mixed saliva was high ( $16 \mathrm{I} \mathrm{m}$-equiv./1.) and differences between animals were small, which suggests that a concentration of about 160 m-equiv./1. may be taken as characteristic of that in the saliva of cows receiving adequate salt.

On the supposition that the $\mathrm{Na}$ content of the mixed saliva of normal cows accurately reflects the state of $\mathrm{Na}$ nourishment, an estimate of $\mathrm{Na}$ requirement could be obtained by determining the minimum amount of $\mathrm{Na}$ needed to maintain the maximum $\mathrm{Na}$ concentration in mixed saliva. An estimate of the requirement for $\mathrm{Na}$ of the cows may be obtained from the results of Expt $\mathrm{x}$. Maximum concentrations of $\mathrm{Na}$ in saliva appeared in the cows consuming hay and dairy cubes; the levels in the saliva of the cows consuming lucerne silage were lower. The daily $\mathrm{Na}$ intakes of the cows consuming these rations were 16.0 and $14.2 \mathrm{~g} /$ day, respectively (Table $\mathrm{I}$ ), and it follows that the requirement must lie somewhere between these two values. The $\mathrm{Na}$ needs of milking cows would, of course, be considerably greater than of the dry cows used in these experiments.

When the cows received adequate $\mathrm{Na}$ the mixed saliva accordingly consisted primarily of solutions of sodium bicarbonate and sodium phosphate with smaller amounts of $\mathrm{K}$ and chloride. This observation supports those of Phillipson \& Mangan (1959) and Emery, Smith, Grimes, Huffman \& Duncan (I960) for cattle and of McDougall (1948) and Hydén (1958) for sheep. The similar mean concentrations of the five inorganic ions in mixed saliva and (Bailey $\&$ Balch, I96r $b$ ) in parotid saliva, both at high rates of secretion (Table $\mathrm{I}$ ), again suggest that the mixed saliva is largely composed of parotid or parotid-like components.

It is possible that in addition to the large fluctuations in the salivary concentrations of $\mathrm{Na}, \mathrm{K}$ and chloride already discussed, there were smaller effects related to differences in the rate of secretion and analogous to the changes in the concentrations of bicarbonate and phosphate. These smaller effects appeared to be present in Expt 5 when, for example, on the 2 Ist and 23rd days (Fig. 2) the rate of secretion of mixed saliva in cow $\mathrm{C}$ was depressed, the concentrations of $\mathrm{Na}$ and bicarbonate in the saliva were low and those of phosphate, $\mathrm{K}$ and chloride were high relative to the concentra- 
tions on other days. It is likely that the variations in the concentrations of $\mathrm{Na}$ and $\mathrm{K}$ between days 25 and 48 were due in some degree to change in the $\mathrm{Na}$ intake. No explanation can be offered for the large transient fall in secretion rate after the administration of sodium chloride, and it is clear that this effect did not persist.

Table I I. Mean composition of mixed and parotid saliva secreted during high rates of secretion in cows receiving adequate intakes of sodium chloride

\begin{tabular}{|c|c|c|}
\hline Constituent & $\begin{array}{l}\text { Mixed } \\
\text { saliva* }\end{array}$ & $\begin{array}{c}\text { Parotid } \\
\text { saliva } \dagger\end{array}$ \\
\hline Sodium (m-equiv./1.) & 161 & I 57 \\
\hline Potassium (m-equiv./1.) & $6 \cdot 2$ & $7 \cdot 0$ \\
\hline Chloride (m-equiv./1.) & $7 \cdot I$ & $7 \cdot 4$ \\
\hline Bicarbonate (m-equiv./1.) & 126 & 127 \\
\hline Phosphate (m-equiv./1.) & 26 & 23 \\
\hline Sum of cations (m-equiv./1.) & 167 & I64 \\
\hline Sum of anions (m-equiv./1.) & I 59 & 157 \\
\hline Dry matter (\%) & $1 \cdot 02$ & $I \cdot 05$ \\
\hline Ash $(\%)$ & 0.89 & 0.91 \\
\hline
\end{tabular}

* Means for some forty-eight samples from four cows receiving diets of hay. $\uparrow$ From Bailey \& Balch (196I $b$ ).

Nitrogenous constituents. Urea $\mathrm{N}$ constituted a variable, but generally high, proportion of the total $\mathrm{N}$ of saliva. The non-urea fraction was relatively constant at $\mathrm{I}-2 \mathrm{mg} \mathrm{N} /$ roo $\mathrm{ml}$ irrespective of the diet.

The salivary urea $\mathrm{N}$ content varied from $\mathrm{I} \cdot 3$ to $14 \cdot 4 \mathrm{mg} / \mathrm{I}$ oo $\mathrm{ml}$ owing to variations in the amount of ammonia produced in the rumen with the different diets and consequent changes in plasma urea levels (Fig. 3). The importance, in the N economy of the animal, of the recycling of dietary $\mathrm{N}$ through the saliva as urea was first pointed out by McDonald (I948) and knowledge of the process was extended by Lewis, Hill \& Annison (1957) and Lewis (r957).

\section{SUMMARY}

r. In cows with rumen fistulas the rate of secretion of mixed saliva was measured by removing part of the digesta from the rumen and collecting the saliva as it emerged from the cardia. Care was taken to prevent stimulation of the region bordering the cardia by contact with the collecting vessel, and it is thought that in consequence the collecting technique did not cause changes in the rate of secretion. The rate of secretion was measured during rest, that is, when the animals were neither eating nor ruminating.

2. Four cows were used to study the rate of secretion I, 4,8 and $14 \mathrm{~h}$ after the beginning of the first of the two daily meals. The rate of secretion was invariably least shortly after a meal and increased as the next meal time approached. The mean rates of secretion differed between diets, being greatest with grass, least with silage and intermediate with (I) hay, (2) hay and dairy cubes and (3) hay, flaked maize and groundnut cake. Neither the changes within one day nor the effects of diets could be related to any change in the physical or chemical characteristics of the contents of the reticulo-rumen. 
3. The addition to the rumen contents of sufficient acetic acid to lower the mean $\mathrm{pH}$ from 6.8 to 5.4 and to increase the total volatile fatty acids from 93 to $167 \mathrm{~m}$-equiv./1. had no obvious effect on the rate of secretion of mixed saliva.

4. In cows given their hay through a fistula the rate of secretion after $I \mathrm{~h}$ was higher than $\mathrm{I} h$ after they had eaten hay, which suggests that the act of eating per se contributes to the establishment of the daily pattern of secretion of mixed saliva.

5. The rate of secretion tended to be greater during periods of rest after small meals than during periods of rest after large ones.

6. In mixed saliva the concentrations of bicarbonate decreased and those of phosphate increased when the rate of secretion fell below $3 \circ \mathrm{ml} / \mathrm{min}$. At higher rates the concentrations of these ions were very uniform irrespective of animal, diet or experiment.

7. Variations, below adequate levels, in the intake of sodium and perhaps of chloride were accompanied by large variations in the concentrations of sodium, chloride and potassium in mixed saliva at all rates of secretion. With adequate intakes of sodium chloride the concentrations in saliva secreted at high rates were similar in all the cows. Aside from the effects of low intakes of $\mathrm{Na}$ and chloride the diets had no significant effect on the composition of saliva.

8. Saliva secreted at high rates by cows receiving adequate sodium chloride typically contained $\mathrm{I} 6 \mathrm{I}$ m-equiv. $\mathrm{Na} / \mathrm{l} ., 6 \cdot 2 \mathrm{~m}$-equiv. $\mathrm{K} / 1 ., 7 \cdot \mathrm{I}$ m-equiv. chloride/l., I $26 \mathrm{~m}$-equiv. bicarbonate/l. and $26 \mathrm{~m}$-equiv. phosphate $/ \mathrm{l}$.

9. The experiments suggested that the daily $\mathrm{Na}$ requirement of these dry cows to prevent changes in the Na content of the saliva lay between 14.2 and $16.0 \mathrm{~g}$.

ro. The concentration of urea in mixed saliva varied with the diets. The mean content of urea nitrogen in the total salivary $\mathrm{N}$ was $77 \%$, and the urea concentration in saliva was consistently above $65 \%$ of the urea concentration of plasma.

II. The mean dry-matter and ash contents of all the samples of saliva were 1.02 and $0.89 \%$ respectively.

I2. The results strongly support the suggestion that the resting mixed saliva consists largely of parotid or parotid-like components.

We thank Dr M. J. Head and Dr J. A. F. Rook for much advice and for help with certain of the analyses, Mr V. W. Johnson and his assistants who, throughout this series of experiments, were responsible for the animals, and Miss L. H. M. Birch, Mr D. Millard and Mr A. W. Wagstaff who kindly carried out the analyses of food and some of the TVFA determinations.

The work reported in this paper was performed during the tenure by one of us (C.B.B.) of a scholarship from the Royal Commission for the Exhibition of 1851 . 


\section{REFERENCES}

Ash, R. W. \& Kay, R. N. B. (1959). F. Physiol. 149, 43.

Bailey, C. B. (1959). Proc. Nutr. Soc. 18, xiii.

Bailey, C. B. \& Balch, C. C. (1961 a). Brit. F. Nutr. 15, 183.

Bailey, C. B. \& Balch, C. C. (1961 b). Brit. F. Nutr. 15, 37 I.

Balch, C. C. \& Johnson, V. W. (1948). Vet. Rec. 6o, 446.

Clark, R. \& Weiss, K. E. (1952). F. S. Afr. vet. med. Ass. 23, 163.

Coats, D. A., Denton, D. A., Goding, J. R. \& Wright, R. D. (1956). F. Physiol. 131, 13.

Coats, D. A. \& Wright, R. D. (1957). F. Physiol. I35, 6II.

Colin, G. (1886). Traité de Physiologie Comparée des Animaux, 3rd ed. Paris: J.-B. Baillière et Fils.

Comline, R. S. \& Titchen, D. A. (1957). F. Physiol. r39, $24 P$.

Conway, E. J. (1957). Microdiffusion Analysis and Volumetric Error, $4^{\text {th }}$ ed. London: Crosby Lockwood and Son Ltd.

Cunningham, H. M. (1958). Canad. F. Anim. Sci. 38, 84 .

Denton, D. A. (1956). F. Physiol. 131, 5 I6.

Denton, D. A. (1957). Nature, Lond., 179, 341.

Dukes, H. H. (1955). The Physiology of Domestic Animals, 7 th ed. London: Baillière, Tindall and Cox.

Ellenberger, W. \& Hofmeister, V. (1887). Arch. Anat. Physiol., Lpz., Suppl. p. I.38.

Emery, R. S., Smith, C. K., Grimes, R. M., Huffman, C. F. \& Duncan, G. W. (1960). F. Dairy Sci. $43,76$.

Hydén, S. (1958). K. LantbrHögsk. Ann. 24, 55.

Kay, R. N. B. (1960). F. Physiol. 150, 5 I5.

Lewis, D. (1957). F. agric. Sci. 48, 438.

Lewis, D., Hill, K. J. \& Annison, E. F. (1957). Biochem. F. 66, 587.

McDonald, I. W. (1948). Biochem. F. 42, 584 .

McDougall, E. I. (1948). Biochem. F. 43, 99.

McManus, W. R. (1959). Nature, Lond., 184, 1572.

Phillipson, A. T. \& Mangan, J. L. (1959). N.Z. F. agric. Res. 2, 990.

Scheunert, A., Krzywanek, F. W. \& Zimmermann, K. (r929-30). Pflig. Arch. ges. Physiol. $223,472$. Weiss, K. E. (1953). Onderstepoort F. vet. Res. 26, 241.

\section{EXPLANATION OF PLATE}

Rubber bag used for the collection of saliva from the cows. 
British Yournal of Nutrition, Vol. I5, No. 3

Plate I

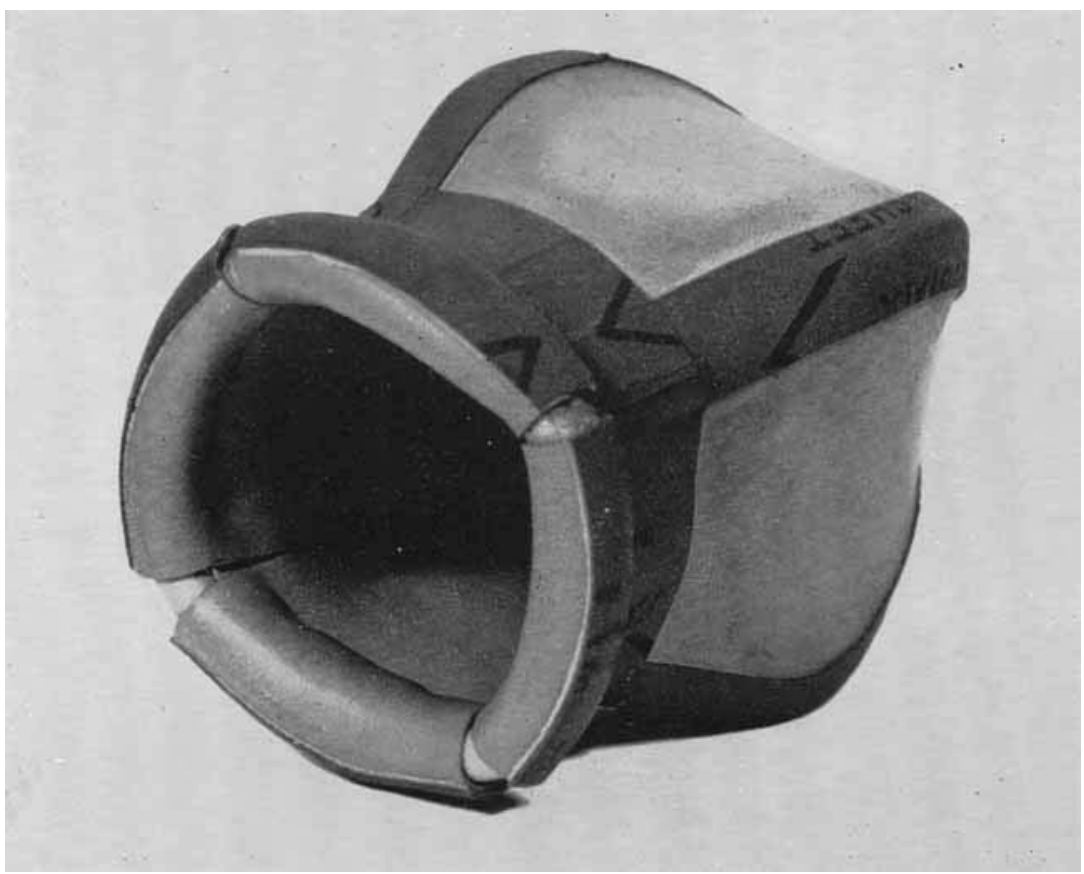

